\title{
Analysis of Field-Aged Pheromone Lures in Cotton Field
}

\author{
${ }^{1}$ Ibrahim Salihu Koko \& ${ }^{2}$ Prof. Alan Cork \\ ${ }^{1}$ Natural Resource Institute (NRI) University of Greenwich United Kingdom. \\ ${ }^{2}$ Agriculture Health and Environment Group Natural Resource Institute (NRI) University of Greenwich United \\ Kingdom
}

\begin{abstract}
The purpose of the paper is to determine the longevity, half life and the release rates of Pheromone lures from three commercial companies in India for the Spodoptera litura. Pheromone lures was extracted and examine by the use of Gas chromatography (GC). The major component was detected as ZE-9, 12: 14Ac. Lures from Natural Resource Institute (NRI), Basarass, Agriland as well as PCI lure for the use on Spodoptera litura was aged in cotton field in India in various dispensers like polyethylene vials, rubber tubes, and rubber septum. The result of this research work shows that the standard NRI lures had their lure impregnated with 0.89mg as initial dose and 5.63\% remaining life at the $6^{\text {th }}$ week. Basarass pheromone company lure had $0.1 \mathrm{mg}$ as initial dose and $12.88 \%$ at the end of $6^{\text {th }}$ week, PCI company lure had $-0.01 \mathrm{mg}$ as initial dose and $7.84 \%$ remaining life at the end of the $6^{\text {th }}$ week, Agriland company lure was impregnated with $0.05 \mathrm{mg}$ as initial dose and $48.02 \%$ remaining life at $6^{\text {th }}$ week respectively. The conclusion that was drawn is that companies like Basarass and Agriland do not put enough milligram ( $\mathrm{mg}$ ) of the major component and the release rates fluctuates on the field due to impurities and this had given the cure some measure of longevity with adverse effect on the performance. Among the recommendations that have been made in this paper companies should endeavor to increase the amount of milligrams impregnated in the lure and find the means and ways of increasing longevity without compromising on the fast release of the major component.
\end{abstract}

Key words: Pheromone, Lures, Cotton.

\section{Introduction}

Cotton is the most important natural textile fiber in the world. Since the end of the second world war, world consumption of textile fibers which includes wool, liner, silk and manmade fibers has risen steadily partly because of a growing population and partly because consumption per head is increasing. Fiber consumption is said to be correlated with income, and while the more developed countries consume 15-20kg per head, many of the developing countries use less than $5 \mathrm{~kg}$ (Munro, 1994). Despite the fact that production is spread out all over the world, for example in 2004 cotton was grown in about 100 countries, production is concentrated in four countries alone which include China, USA, India and Pakistan, and these mentioned countries collectively account for approximately two thirds of the world output (http://ro.unctad.org/infocomm/ang/als/cotton/market.htm). The leading cotton producing countries of Asia are China, India Pakistan and Uzbekistan while the leading cotton exporters in Asia are Uzbekistan and India (Narayanamoorthy, 2006). Narayanamoorthy (2006) further opined that pest /insect constituted hindrance to cotton productivity in India which led to low yield despite using chemical pesticide the control of such pest is still fruitless which led to introduction of biological pesticide.

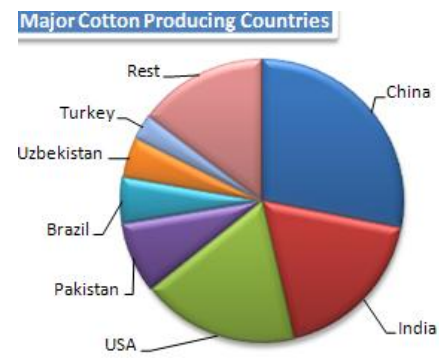

Major Cotton Producing Countries in 2011

Adapted from: globalbhasin.blogspot.com 2012

Cotton is one of the most important cash crops in India and also it plays a vital role in the national economy. Cotton is an industrial crop in India; it helps millions of people through cultivation, processing and trade. 
Production of cotton in India contributes Rs 360 billion (US \$8 billion) to the national export income (Monsanto, 2007; Narayanamoorthy, 2006). The Indian sub-continent has been famous for the production and use of cotton from the beginning of recorded history (Berger, 1969). Kranthi et al. (2004) noted that cotton is cultivated mainly in about 9 million hectares (5\% of the total arable land area) in nine states (Punjab, Haryana, Rajasthan, Gujarat, Maharashtra, Madhya Pradesh, Kamataka, Tamilnadu and Andhra Pradesh) across the country.

India is said to have the largest area under cotton cultivation in the world (representing 20-25\% of the global area) but it ranks only third in terms of production after China and USA. Several factors contribute towards such low yields, of which losses due to insect pests are the most important. More than 160 species of insect have been reported to pose problems on cotton at various stages of its growth, including defoliators, tissue borers and sap suckers causing losses up to $60 \%$. Among all the species that attack cotton in India, bollworms are the most destructive, requiring major efforts to save the crop from them (Narayanamoorthy, 2006).

\section{Table 1: Quantity of Pheromone Products of Different Insect Species Sold Per Year by Smes in India INSECT SPECIES QUANTITY OF LURES ('000s)}

$\begin{array}{lc}\text { Helicoverpa armigera } & 830 \\ \text { Spodoptera litura } & 480 \\ \text { Earias vitella } & 280 \\ \text { Pectinophora gossypiella } & 130 \\ \text { Leucinodes orbonalis } & 10 \\ \text { Scirpophaga incertulas } & 20 \\ \text { Plutella xylostella } & <10 \\ \text { Rhynchophorous ferrugineus } & <10 \\ \text { Odoiporus longicollis } & <10 \\ \text { Homona coffearia } & <10 \\ \text { Spodoptera exigua } & <10 \\ \text { Bactrocera dorsalis } & <10\end{array}$

\section{Adapted from Cork (2004)}

The table above shows that, Helicoverpa armigera, Spodoptera litura and Earias vitella are the species for which the highest quantity of pheromone lures are sold per year by SMEs in India, which gives some indication of their economic importance in the region.

The Natural Resource Institute (NRI) of United Kingdom has worked closely with a range of commercial companies in South Asia in order to improve the quality and cost-effectiveness of pheromone lures for use in insect pest population monitoring and control. As part of this action, field and laboratory studies are being conducted to assess the properties of commercial pheromone lures compared to standard NRI lures. Pheromone lures for the leafworm, Spodoptera litura was provided by three Indian companies and placed in pheromone traps in the field. Each week four lures were randomly collected from each company's set of lures and stored at $-20^{\circ} \mathrm{C}$. At the end of the sixth week the lures were sent back to NRI for analysis of residual pheromone content.

In many circumstances the faster the pheromone releases from a lure the more moths are attracted and so the more effective the lure. However, for a given dose the faster the compounds are released the shorter the field life. Ideally farmers want an effective lure (fast release) that last for a long time, thus a balance needs to be struck between these extremes. Generally lures are manufactured to have a field life of about one month, but this can be extended up to one year for some species. Often commercial companies try to impress farmers with high catches in the first week but the lures may not persist for much longer. This study for the first time compared commercial lures and provides a comparative measure of release and persistence and so provides farmers with a means of deciding which lures are best suited to their needs.

\section{Literature Review}

Use of pheromone traps for control by monitoring population: Increasingly, pheromones are being used to determine when pests enter crops or when numbers have built up sufficiently to warrant control measures being taken or to predict the correct timing for such measures. Not only can the use of pheromones greatly improve the correct timing of insecticides sprays, but the simplicity of visiting and counting insects in one or two traps in or around crops makes it a tool which is easy for the farmer to use. The traps used in monitoring insect pests are usually fairly simple in design, often little more than a polythene bag attached to a paraffin funnel or a small metal or cardboard roof with a sticky floor on which the insect s arriving at the trap caught. A synthetic pheromone is used and can be released slowly from a small rubber or polythene capsule in the roof of the trap (Van Emden, 1989). One 
example of monitoring a cotton pest on a country-wide basis is that of the lesser cotton leaf worm (Anomis texana) in Peru (South America). This pest is often causes severe damage to cotton. Dr David Hall and his colleagues of ODNRI identified the pheromone of Anomis texana as two component mixture. The pheromone was field tested by Mr. Chamberlain of ODNRI in the vicinity of Ica. In some instances he was able to catch over 1000 moths per trap per night (Critchly et al. (1989). According to Srivastava et al. in Cork 2004 reported that flight pattern of Helicoverpa armigera were successfully monitored in Pakistan and India using pheromone monitoring traps. However, Wightman and Ranga Rao in Cork (2004) reported that the inability to utilize pheromone traps to predict damage could be due to an inappropriate pheromone blend.

Use of pheromone traps for control by lure and kill: according to Critchley et al., (1989) the principle of this method of control is male annihilation by attracting male moths to discrete points sources which are spiked with contact insecticide. Similarly De Souza et al, (1992) reported that potential for using combination of pheromone and insecticide as a means of insect pest control have been suggest by a number of outhouse. Insects (generally males) are attracted to contact insecticide-treated pheromone release site and are then incapacitated.

Successful Application of lure and Kill Approach on Insect pests of Cotton: According to Van Emden (1989) successful application of lure and kill pheromone traps was obtained against pink bollworms (Pectinophora gossypiella) on cotton in the USA where economic threshold for the pest is reasonable high. The traps where set out at 12 per hectare in the spring and increased to 50 per hectare in the season. Attack of the bolls was monitored, and sprays were applied when more than $10 \%$ were attacked. The technique certainly reduced the need for pesticide.

The cotton weevil Anthonomos grandis is a major pest of cotton in the America's. male pheromone of this pest has been successfully incorporated into a 'bait stick' known as Boll weevil attract and control tubes (BWACT) over $1,000,000$ tubes are produced by plato industries in the USA per year providing successful control of this insect pest of cotton in the USA, South America etc. (Cork 2004).

Experimental controls using lure and kill: since the introduction of commercial formulations of mating disruption pheromone Gossyplure, efforts to develop more efficacious formulations have led to the concept of adding an insecticide to the adhesive used of the gossyplure substrate to the cotton plant. The resultant 'attracticide' given a lethal or sub lethal dose of insecticide to the pink bollworm insects upon contact, hence temporarily or permanently removed from the reproductive population. (Miller et al. 1990). Similarly, in another related studies carried out by Downham et al. (1995) showed that the use of pheromone formulation 99.1 which is a mixture of Z,E-9-11 tetradecadenyl acetate and Z,E-9-12 tetradecadenyl acetate in conjunction with pyrethroid insecticide $\infty_{\text {cyhalothrin }}$ in 500 point-sources/ha at low rates of application of both components gave good control on Egyptian cotton leaf worm Spodoptera lituralis.

Limitation of lure and kill pheromone traps: According to Van Emden (1989) mathematical models suggest 90\% of the male catch using lure and kill traps have to be killed before next generation would be reduced, let alone brought down to grower-acceptable levels. Critchley et al., (1989) noted that there is still the problem of finding the ways and means to encourage male moths to remain in contact with the insecticide spiked pheromone sources long enough to pick up a lethal or sub lethal dose.

\section{Material And Methods}

Pheromone lures were obtained from three commercial companies in India which were Basarass, Agriland as well as PCI lures. The NRI lure was used as the standard lure for making comparison. The lures were aged in pheromone traps in a cotton field. Each week four (4) lures were randomly collected from each company set of lures and they were stored at $-20^{\circ} \mathrm{C}$. The collection process was continued each week until the end of week six. They were then sent to NRI for the analysis of residual pheromone content. The zero (0) week set of lures were not placed in the field; they were fresh, unexposed lures. When the lures arrived in NRI they were stored in a freezer until analysis.

Extraction of pheromone from the lures: The pheromone lures were individually placed in a $10 \mathrm{ml}$ bottle; lures that were in the form of vials were cut into two in order to give more chance for the solvent to extract the pheromone content properly. The $10 \mathrm{ml}$ bottles containing the lures were labeled according to each company's name and then hexane added $(5 \mathrm{ml})$ as a solvent containing internal standard (1 $\mathrm{mg}$ of dodecyl acetate (12:Ac) the lures were then kept in a freezer until the time for Gas chromatography analysis of the residual pheromone.

Gas chromatography analysis of residual pheromone: Gas chromatography analysis of the residual pheromone was performed with a Agilent 6890 equipped with a DBWax fused silica capillary column (30m long, 0.32 internal diameter, $250 \mu \mathrm{m}$ film thickness) using a split/split less inlet and flame ionization detector at $240^{\circ} \mathrm{C}$. The carrier gas was helium at a pressure of $0.8 \mathrm{~kg} / \mathrm{cm}^{2}$. The gas chromatographic data were collected and processed using "EZchrom Elite 3.0". 
Statistical analysis: The percentage of the pheromone remaining from each lure of each company was computed using Microsoft Excel. Chart wizard was used to plot charts for the amount of pheromone remaining from the lures in order to determine the half life and release rates, as well as the longevity of the pheromone lure in the field.

\section{Data presentation and analysis}

Table 2:-Amount of pheromone remaining in duplicate samples of the NRI lure according to gas chromatographic analysis

\begin{tabular}{|c|c|c|c|}
\hline Week & $\begin{array}{c}\text { Mean pheromone remaining } \\
(\mathbf{m g})\end{array}$ & Release rate per week & $\begin{array}{c}\text { Percentage remaining } \\
(\%)\end{array}$ \\
\hline 0 & 0.89 & & 100 \\
\hline 1 & 0.32 & 0.57 & 36.35 \\
\hline 2 & 0.20 & 0.12 & 22.38 \\
\hline 3 & 0.12 & 0.08 & 13.93 \\
\hline 4 & 0.07 & 0.05 & 8.36 \\
\hline 5 & 0.06 & 0.01 & 6.26 \\
\hline 6 & 0.05 & 0.01 & 5.63 \\
\hline
\end{tabular}

Source: Field work 2012

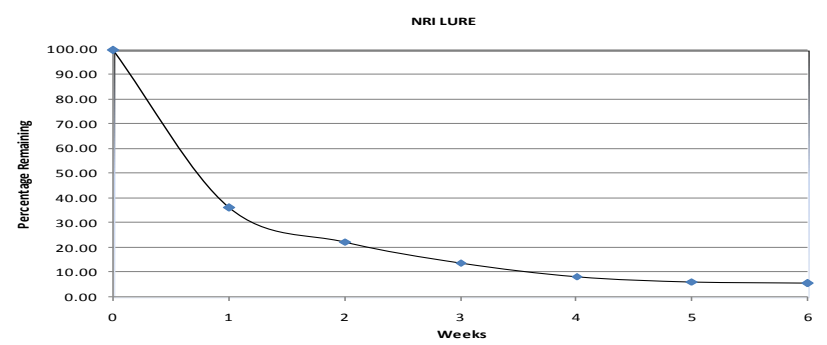

Fig 1: Decline of amount of pheromone remaining in samples of the NRI lures with age

Table 2 shows that the NRI lure contained an initial mean dose of $0.89 \mathrm{mg}$, releasing $0.57 \mathrm{mg}$ of the major component during the first week of exposure, equating to an amount remaining of $36.35 \%$ of the initial value. In subsequent weeks the amounts remaining of $22.38 \%, 13.93 \%, 8.36 \%, 6.26 \%, 5.63 \%$ respectively to the end of week six.

Table 3:- Amount of pheromone remaining in duplicate samples of the Agriland lures according to gas chromatographic analysis

\begin{tabular}{|l|l|l|l|}
\hline Week & Mean Value $(\mathbf{m g})$ & $\begin{array}{l}\text { Release rate per } \\
\text { week }\end{array}$ & $\begin{array}{l}\text { Percentage } \\
\text { remaining weekly }\end{array}$ \\
\hline 0 & 0.75 & & 100 \\
\hline 1 & 0.69 & 0.06 & 92.02 \\
\hline 2 & 0.65 & 0.04 & 86.80 \\
\hline 3 & 0.53 & 0.12 & 70.42 \\
\hline 4 & 0.43 & 0.1 & 56.77 \\
\hline 5 & 0.41 & 0.02 & 54.99 \\
\hline 6 & 0.36 & 0.5 & 48.02 \\
\hline
\end{tabular}

Source: Field work 2012 
Agriland Lure

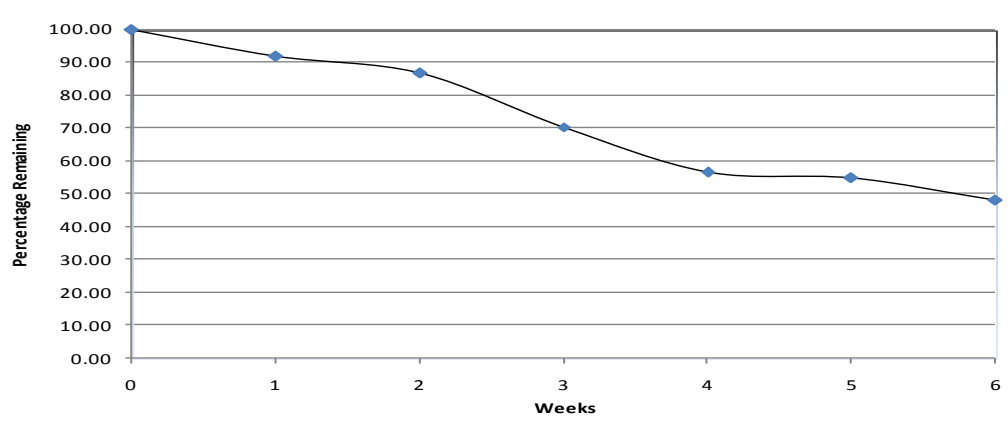

Fig. 2 Decline of amount of pheromone remaining in samples of the Agriland lures with age

Table 3 shows that the Agriland lure have initial mean dose value of $0.75 \mathrm{mg}$, releases $0.06 \mathrm{mg}$ of the major component with a corresponding $92.02 \%$ remaining life passes through the release rates of $0.04 \mathrm{mg}$, $0.12 \mathrm{mg}, 0.1 \mathrm{mg}, 0.02 \mathrm{mg}, 0.05 \mathrm{mg}$ and subsequent remaining value of $86.80 \%, 70.42 \%, 56.77 \%, 54.99 \%$, $48.02 \%$ accordingly till the end of maturation age of pheromone in week six.

Table 4: Amount of pheromone remaining in duplicate samples of the PCI lures according to gas chromatographic analysis

\begin{tabular}{|l|l|l|l|}
\hline Week & Mean Value $(\mathbf{m g})$ & Release rate per week & $\begin{array}{l}\text { Percentage remaining } \\
\text { weekly }\end{array}$ \\
\hline 0 & 0.84 & & 100 \\
\hline 1 & 0.51 & 0.33 & 60.93 \\
\hline 2 & 0.28 & 0.23 & 32.95 \\
\hline 3 & 0.13 & 0.15 & 15.03 \\
\hline 4 & 0.13 & 0.00 & 15.85 \\
\hline 5 & 0.06 & 0.07 & 7.31 \\
\hline 6 & 0.07 & -0.01 & 7.84 \\
\hline
\end{tabular}

\section{Source: Field work 2012}

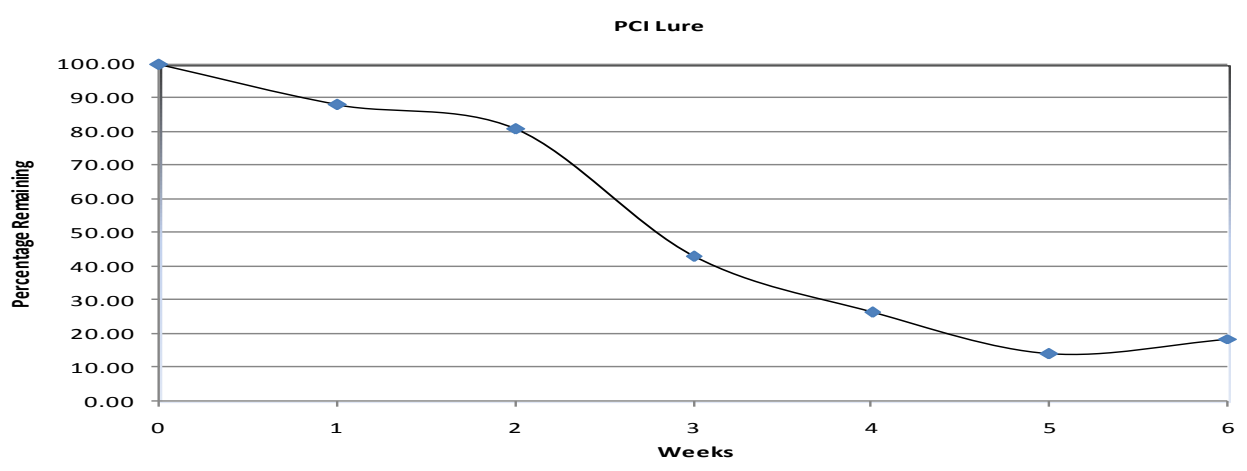

Fig. 3 Decline of amount of pheromone remaining in samples of the PCI lures with age

Table 4 shows that the PCI lure have initial mean dose value of $0.84 \mathrm{mg}$, releases $0.33 \mathrm{mg}$ of the major component with a corresponding $60.93 \%$ remaining life passes through the release rates of $0.23 \mathrm{mg}, 0.15 \mathrm{mg}, 0.00 \mathrm{mg}, 0.07 \mathrm{mg}$, $0.01 \mathrm{mg}$ and subsequent remaining value of $32.95 \%, 15.03 \%, 15.85 \%, 7.31 \%, 7.84 \%$ accordingly till the end of maturation age of pheromone in week six. 
Analysis of field-aged pheromone lures in cotton field

Table 5:-Amount of pheromone remaining in duplicate samples of the Basarass lures according to gas chromatographic analysis

\begin{tabular}{|l|l|l|l|}
\hline Week & Mean Value $(\mathbf{m g})$ & Release rate per week & $\begin{array}{l}\text { Percentage remaining } \\
\text { weekly }\end{array}$ \\
\hline 0 & 0.70 & & 100 \\
\hline 1 & 0.53 & 0.17 & 75.12 \\
\hline 2 & 0.37 & 0.16 & 52.70 \\
\hline 3 & 0.58 & -0.21 & 82.80 \\
\hline 4 & 0.27 & 0.31 & 37.92 \\
\hline 5 & 0.19 & 0.08 & 26.53 \\
\hline 6 & 0.09 & 0.1 & 12.88 \\
\hline
\end{tabular}

Source: Field work 2012

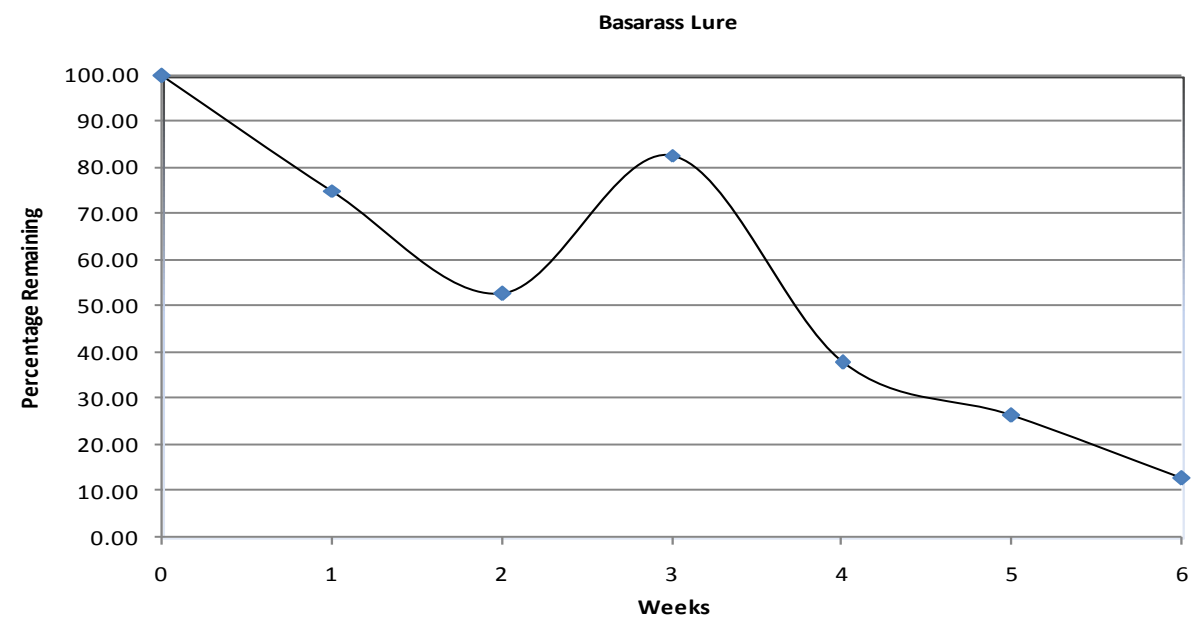

Fig. 4 Decline of amount of pheromone remaining in samples of the Basarass lures with age

Table 5 shows that the Basarass pheromone lure have initial dose value of $0.70 \mathrm{mg}$, releases $0.17 \mathrm{mg}$ of the major component with a corresponding $75.12 \%$ remaining life passes through the releases rates of $0.16 \mathrm{mg},-0.21 \mathrm{mg}$, $0.31 \mathrm{mg}, 0.08 \mathrm{mg}, 0.1 \mathrm{mg}$ and subsequent remaining value of $52.70 \%, 82.80 \%, 37.92 \%, 26.53 \%, 12.88 \%$ accordingly till the end of maturation age of pheromone in week six.

\section{Discussion}

Commercial lures from three companies was aged for six weeks in cotton field in India in polyethylene vials, rubber tube, rubber septa in a trap, ZE9,12-14Ac was detected as the major component. The NRI lures which is in a polyethylene vial indicated a release rate that will prove maximum period of attractiveness. It shows a fast release rate and also showed consistency of performance with age, which implies that the lure will catch enough and also persist. This is in conformity with the findings of David (1986) while conducting a field comparison of spruce budworm pheromone lures; indicated that lures with highest release rate consistently caught the most. Agriland lure is contained in a septum with a mean value of $0.75 \mathrm{mg}$ and $100 \%$ remaining life at week zero (0). The lure was also exposed for $0,1,2,3,4,5 \& 6$ weeks. By the end of the first week it had a release of $0.06 \mathrm{mg}$ and remaining half life of $92 \%$, meaning there was very slow release at the beginning week. It reaches it half life between week 5 and six. Throughout the age of exposure there was very slow release of the component and the farmer can have the benefit of having the pheromone in the lure with some degree of attractiveness for about six weeks. See fig. 2. In contrast the PCI lure which was also contained in a polyethylene vial dispenser had $0.84 \mathrm{mg}$ mean value of major component at week zero with $100 \%$ remaining life. Exposed for 0, 1, 2,3,4,5 \& 6 weeks, it had $60.93 \%$ remaining life at the end of week one with a release of $0.33 \mathrm{mg}$. It attains it half life between week one and two. Maximum attractiveness takes place within this period; it declines at constant rate for the rest of the weeks reaching a $7.84 \%$ remaining life at the matured age of week six. The constant decline is an indication of good pheromone slow decline. There is attraction for most of the period of the age of the lure.

Basarass lure with a mean value of $0.70 \mathrm{mg}$ and remaining life of $100 \%$ at week zero were put in rubber septum dispensers and aged six weeks. Exposure for weeks $0,1,2,3,4,5$ \& 6 was conducted in India. The 
pheromone had a remaining life of $75.12 \%$ at the end of the first week with a release of $0.17 \mathrm{mg}$. It reaches its half life between week 3 and 4 . There were fluctuations in the release of the pheromone between the first and the third week with slow decline between week 4 and 6 . It had a remaining life of $12.88 \%$ at the end of the sixth week. Its maximum attractiveness was between week 1 and 3. Also see fig 4 . However it is noticeable that even at the end of the maturation age of six weeks there is still some pheromone activity.

\section{Conclusion}

The employment of pheromones to control the populations of the leaf worm (Spodoptera litura) in India can become more popular if the pheromone lures can be made effective in terms of catch and also the prices of the lures. In many instances the faster the pheromone releases from the lure the more moths are attracted. However, with the six weeks of age or maturation of the pheromones lure, the fast releases result into the pheromones half life being reached within short period of time thereby affecting its longevity. In this regards the standard NRI lure strikes a balance which result the half life being reached in the second week of exposure. Gradual decline is the characteristics of good pheromone lure, and the standard NRI pheromone lure superseded all the rest of the companies in good gradual decline. The PCI pheromone lure follows the NRI pheromone lure in terms of good gradual decline, however, fluctuations at certain period of the age of the exposure shows it cannot match that of NRI in terms of purities which can cause fluctuations. Others that go to the extreme of the slow decline would result into lesser catch but longer persistence of pheromone lure in the field. Generally farmers are interested in both longevity and effective lure catch. The Agriland pheromone lure fall into this category, it has very slow release but long persistence in the field and this is only one aspect of the farmer's desire.

The type of the trap and dispensers seems to affect longevity and release of the pheromone. The standard NRI lure and the PCI lure that were in a polyethylene vials had almost exponential decline reaching half life within two weeks of age. Compared to Agriland and Basarass lures that are in a rubber septum lure which has some fluctuation of the release, Agriland lure had a longer half life but releases below expectations.

\section{Recommendations}

1. Companies like Agriland and Basarass whose lures was impregnated with less than $0.80 \mathrm{mg}$ of the major component should increase the dose to a recommended dose so that the lures could have both longevity and attractiveness in such a manner that the farmer is well off.

2. Companies like Basarass and Agriland that are using rubber septum as the dispensers should improve to be using polyethylene vials since all the companies that has a good decline are using polyethylene vials as their dispensers.

3. Agriland Company should work on how to balance between the release rate and the persistence in the field.

4. There should be good government policies in place to regulate the trade in pheromone whereby license is only issued to companies that meet the standard in terms of release and persistence of their lures.

5. The price of the pheromone should be affordable to the farmers.

\section{References}

[1] Cork, A.: Enabling small and medium enterprises to promote pheromone based pest control technologies in South Asia, Natural Resource Institute (NRI), Chatham Maritime, 6-36. (2004)

[2] Crithcley, B.R., Campion, D.G. and Mc Veigh, L.J.: "Pheromone control in the integrated pest management of cotton" in Green, M.B. de, D.J. and Lyon, B. (eds) pest management in cotton, Ellis Horwood Limited, Chichester, 83-87 (1989).

[3] David G.G.: Field comparison of spruce budworm pheromone lures, United State Department of Agriculture, Northeastern Forest Experiment Station research note NE-339 (2) (1986).

[4] De Souza, K.R., Mc Veigh, L.J. and Wright D.J.: "Selection of insecticides for lure and kill studies against Spodoptera lituralis (Lepidoptera: Noctuidae) in journal of economic entomology, 85 (6): 2100 (1992).

[5] Downham, M.C.A., Moawad, G.M. and Mc Veigh, L.J.: Field investigation of an attracticide control technique using the sex pheromone of the Egyptian cotton leaf worm, Spodoptera lituralis (Lepidoptera: Noctuidae) in Bulleting of Entomological Research, 85, 463-472(1995).

[6] Kranthi, K.R., Banerjee, S.K., Sheo R., Mayee, C.D and Russell, D.A.: New vistas in IRM based cotton IPM in India World research conference 3, Cape Town, South Africa (2004). Extracted from http//Whalolab.msu.edu/rpmnews/vol.14.no.i/globe/rpm-gKranthi-et al .htm-2lk

[7] Miller, E., Staten, R.T.,Nowel, C.and Gourd, J.: "pink bollworm (Lepidoptera: Gelichiidae): point source destiny and its relationship to efficacy in attraticide formulations of Gossyplure" in journal of economic entomology, 83 (4) (1990).

[8] Munro, J.M. cotton and its production in G.A. Mathews and J.P. Tustall, insect pests of cotton, cab international, Oxon. P 3 (1994).

[9] Narayanamoorthy A. and Kalamkar S.S.: Is Bt cotton cultivation economically viable for Indian farmers? An empirical Analysis, economic and political weekly, 41, (26) Pp 2716-2717, (2006).

[10] Van Emden, H.F. Pest control, Edward Arnold, London, 2nd Edition, $42-43$ (1989).

[11] globalbhasin.blogspot.com 